\title{
Evaluation under Laboratory Conditions of the Efficacy of Four Extracts of Spontaneous Plants from the Mzab Valley (Algeria) against the Date Palm Mite (Oligonychus afrasiaticus)
}

Younes Babaz, Omar Guezoul, Laboratoire des Bio-ressources Sahariennes: Préservation et Valorisation, Département des Sciences Agronomiques, Faculté des Sciences de la Nature et la Vie et Sciences de la Terre. Université Kasdi Merbah, BP 511, Ouargla 30000, Algeria, and Noureddine Bouras, Département de Biologie, Faculté des Sciences de la Nature et de la Vie et Sciences de la Terre, Université de Ghardaïa, 47000 Ghardaïa, Algeria https://doi.org/10.52543/tjpp.16.2.2

(Algeria)

\begin{abstract}
Babaz, Y., Guezoul, O., and Bouras, N. 2021. Evaluation under laboratory conditions of the efficacy of four extracts of spontaneous plants from the Mzab Valley (Algeria) against the date palm mite (Oligonychus afrasiaticus). Tunisian Journal of Plant Protection 16 (2): 29-41.

Trials were conducted to test the hydrosols of 4 spontaneous plants on the date palm mite, Oligonychus afrasiaticus, a key pest of date palm in Algeria. Extracts from those plants (basil, harmel, colocynth and hyssop) tested against date palm mite showed promising results. The quantities of essential oils extracted from the 4 plants were extremely low, that is why only hydrosols were used. The results obtained change depending on the number of sprays and the reading time after treatment. The hyssop extract caused a high mortality rate of $91 \%$, followed by colocynth and basil extracts with average mortality rates of $64 \%$ and $62 \%$, respectively. The lowest mortality rate, $6 \%$, occurred when applying harmel extract.
\end{abstract}

Keywords: Date palm, mite, Oligonychus afrasiaticus, plant extracts, septentrional Sahara, spontaneous plant

Among the pests of date palm (Phoenix dactylifera), the scale insect Parlatoria blanchardi, the moth Apomyelois (syn Ectomyelois) ceratoniae, the black borer Apate monachus, and the mites Oligonychus pratensis (syn Paratetranychus simplex) and Oligonychus afrasiaticus are the most

Corresponding author: Younes Babaz

Email: babazyounes@gmail.com

Accepted for publication 11 September 2021 important. The latter species causes serious scars on the fruits, sometimes so severe that the dates become brown with a crusty appearance. The skin of infested fruits becomes hard, then cracks and wrinkles, reducing the quality and making such fruit unmarketable (Hussain 1974; De Montaigne and Fall 1986; Guessoum 1986). The various control methods available have not provided the desired level control of mites in palm groves, particularly chemical pesticides. Hence, the overuse of pesticides (acaricide) has shown multiple negative side effects, and 
several disadvantages have been noted after the use of these synthetic products (Doumandji-Mitiche and Doumandji 1993). The intensive use, and sometimes overuse of chemicals to control Oligonychus afrasiaticus, resulted in multiple resistance cases (Hay and Waterman 1993; Singh and Upadhyyay 1993; Isman 2000, 2001; Chiasson et al. 2001; Basta and Spooner-Hart 2002). However, natural plant extracts can be the source of a large number of acaricide and insecticide products (Isman 2001).

There is growing interest from farmers in biopesticides, including their use in integrated pest management strategies (Jovana et al. 2014). Biopesticides could be defined as "living organisms or products of these organisms with the ability to limit or suppress crop pests" (Thakore 2006). It is in biopesticides that we search for alternatives to control Oligonychus afrasiaticus through appropriate integrated control trials in palm groves, in the Mzab region, Algeria (Fig. 1). Biological control through the use of plant extracts could provide alternatives to chemical control and may be combined with other control methods that are not harmful to the environment.

Extracts of some plant species have been shown to act as biopesticides against other pest species. This includes Peganum harmala (Zygophyllaceae), which is toxic to the desert locust Schistocerca gregaria when digested (Idrissi Hassani et al. 2008). Abbassi et al. (2003) reported that the use of $P$. harmala leaf extracts on female desert locusts leads to reduce food intake, motor skills, and disturbances of the reproductive function. Moreover, Bruneton (2016) reported that the hyssop contains pinocamphone and isopinocamphone, which are neurotoxic ketones (causing convulsions and tetany).
Neurotoxicity may be related to the inhibitory action of these ketones on cellular respiration. Akono et al. (2012) reported that Ocimum basilicum oil contains a majority of monoterpene hydrocarbons $\quad(56.2 \%)$. Bioassays undertaken according to the World Health Organization (WHO) standard protocol showed that these volatile essences have remarkable insecticidal properties.

The purpose of this work is to evaluate the acaricidal effect of plant extracts (hydrosol) against the date palm mite, Oligonychus afrasiaticus, which causes enormous damages to date production in the region. Four plant species were collected in the area of Touzouz (Municipality of Ghardaïa), and N'tissa (Municipality of Bounoura), during the month of July 2018. From these plants, the active ingredients were extracted, in order to test their efficacy, under laboratory conditions, as bioacaricid to control this mite of date palm.

\section{MATERIALS AND METHODS Plant materials.}

Four plant species were used for the extraction of essential oils (EO) and the recovery of their hydrosols: Ocimum basilicum (basil), Hyssopus officinalis (hyssop), Peganum harmala (harmel) and Citrullus colocynthis (colocynth) (Fig. 2).

The plants were collected at dawn, then left out to dry in the shade for few days. The entire aerial part was used in the extraction procedure. Two plants (basil and hyssop) were collected from Touzouz area (Ghardaïa municipality, Ghardaiia governorate) in a palm grove operating in an oasis production system (date palms, arboriculture and vegetables). However, harmel and colocynth were collected from a natural non-cultivated environment from N'tissa area (Bounoura municipality, Ghardaïa governorate). 


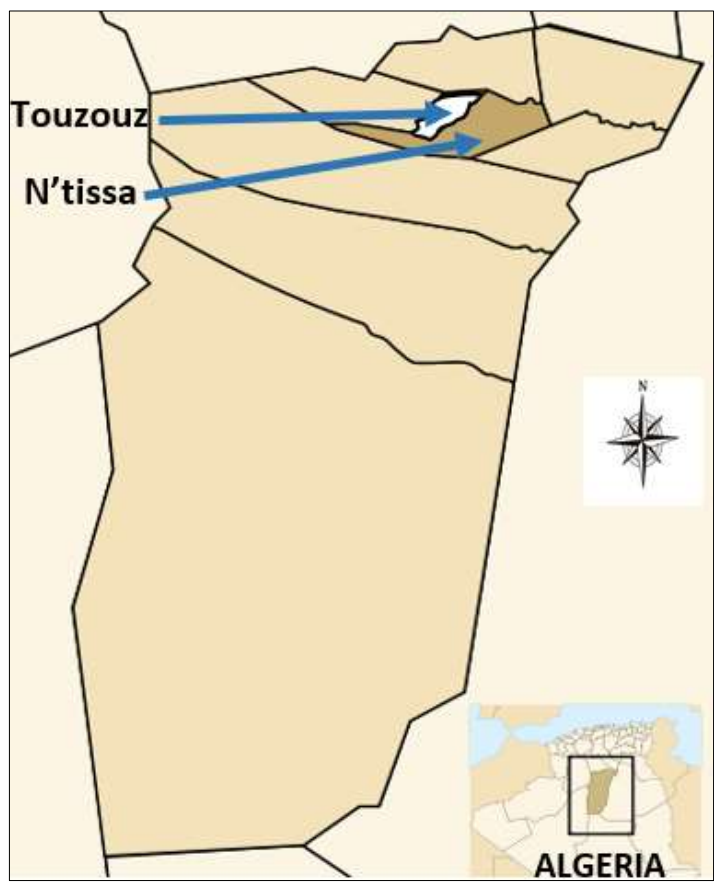

Fig. 1. Geographical location of Tzouzou and N'tissa areas in Ghardaïa governorate.
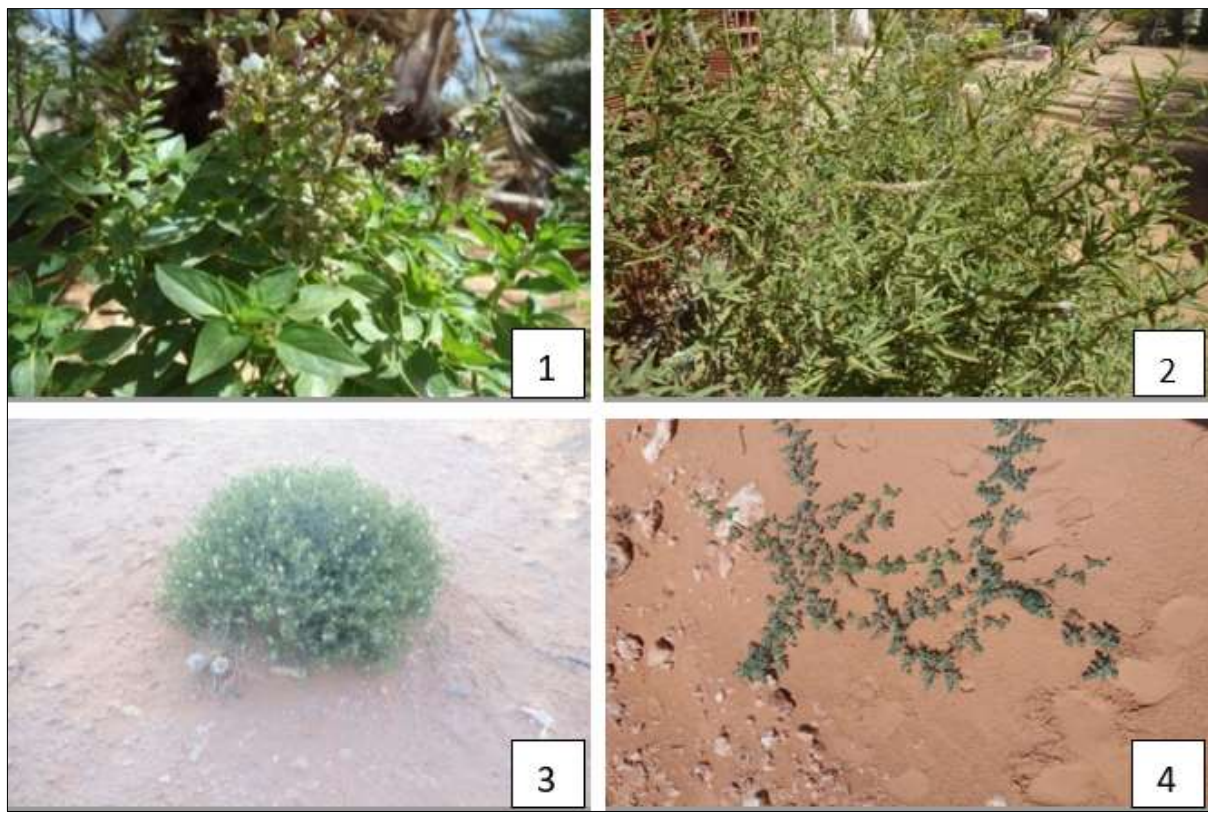

Fig. 2. Basil (1), Hyssop (2), Harmel (3) and Colocynth (4). 


\section{Extraction process and determination of extraction yield.}

The selection of an extraction method depends on the quality sought and on the nature of the plant material to be extracted. Extraction of the essential oil and hydrosol were carried out under laboratory conditions by using an hydrodistillation procedure (both essential oil and hydrosol were collected by the same technique). The operation consists in immersing the aerial parts of the dried plant into a round bottom flask of 2 liters volume, filled with distilled water up to $2 / 3$, then boiled for $4 \mathrm{~h}$. The essential oil is then driven by water vapor and condensed through the capacitor. The collected liquid results in a distillate with a thin layer of oil on the surface, which will be separated with a settling bulb, after resting the liquid. The collected hydrosol is stored hermetically in sealed glass bottles and kept under cool conditions.

According to AFNOR (1986), the yield of essential oil (EO) is defined as the ratio between the mass of the essential oil obtained after extraction ( $\left.\mathrm{M}^{\prime}\right)$ and the mass of the plant material used (M). It is given by the following formula:

$$
\mathrm{EO}=\left(\mathrm{M}^{\prime} / \mathrm{M}\right) \cdot 100
$$

where EO: Essential oil yield of each plant, M': Mass of the obtained essential oil (g), M: Mass of the used plants (g).

\section{Mite collection.}

Infested date fruits of cultivar Deglet-Nour were used as the source of mites (Fig. 3). Mites move quickly from infested to healthy fruits. The initial number of mobile mites (larvae, protonymphs, deutonymphs and adults) was counted prior to each treatment (after placing the mite boxes in the refrigerator at $4^{\circ} \mathrm{C}$ for $30 \mathrm{~min}$, to slow down the activity of mites). The starting number of mite individuals was adjusted to 100 , no matter the stage, by gently removing additional mites with a very fine brush.

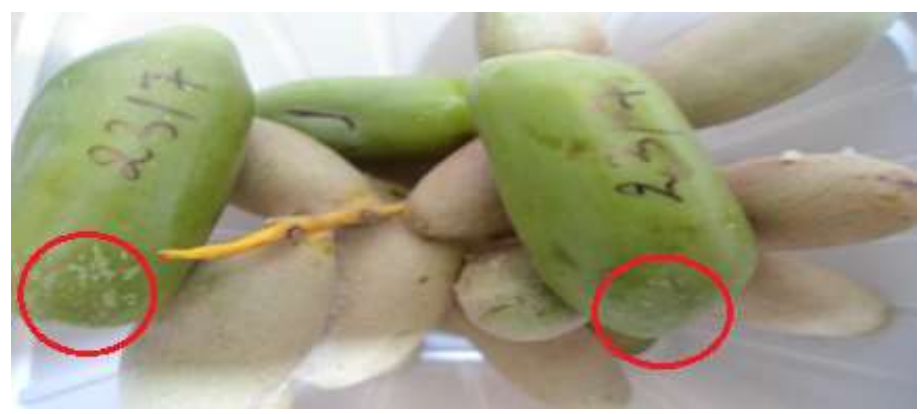

Fig. 3. Migration of mites from infested to healthy date fruits (inside the circles).

\section{Treatments.}

Manual sprayer $(500 \mathrm{ml})$ was used for all treatments of the mite individuals on fruits under constant temperature and humidity of $32^{\circ} \mathrm{C}$ and $20 \%$, respectively, in the laboratory. The treated fruits were placed in four plastic boxes $(30 \times 20 \times 15 \mathrm{~cm})$, lined with blotting dry paper and covered by Muslin fabric. The hydrosol of each plant was applied to three fruits. One spray of the sprayer delivers a $0.80 \mathrm{ml}$ volume. The 
number of sprays ranged from one to four, resulting in a total treatment volume from 0.8 to $3.2 \mathrm{ml}$ (Fig. 4). There were three replicates for each treatment plus one negative control (with only water) common to all plants. Over time, four measurements spaced of two hours (after
2, 4, 6 and 8 hours) were performed to determine the mite mortality rates which were evaluated by counting the living and dead mites before and after treatment, using a binocular magnifier and an electronic hand meter.

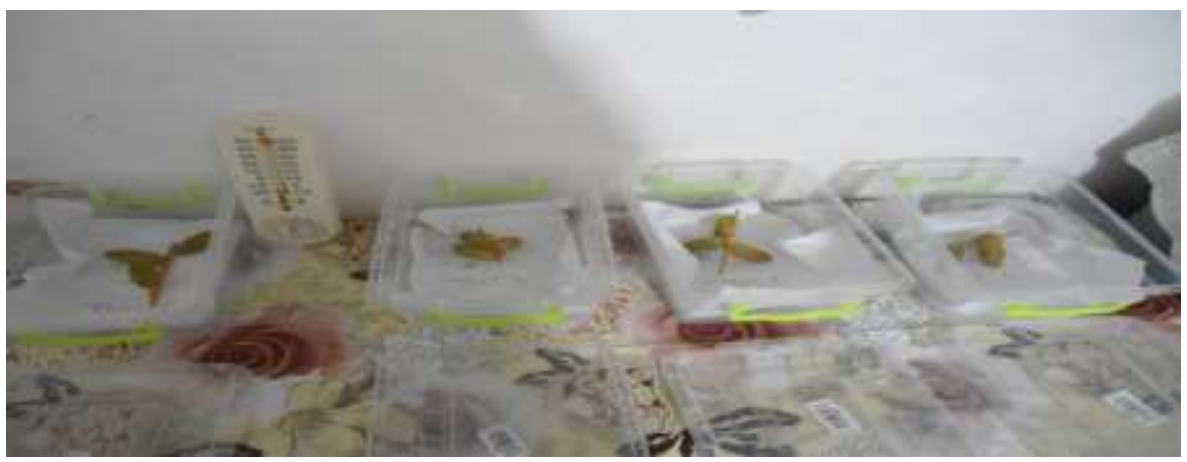

Fig. 4. Treatments of three dates in each plastic box and each treatment was replicated three times.

\section{Statistical analysis.}

We compared the mite mortality rates associated with the different plant hydrosol treatments, using statistical analysis performed in R software (1953). We therefore verified the Shapiro-Wilk normality test, then adopted the KrukalWallis test to compare mortality rates under the influence of various factors, namely, plant species, number of sprays and timing of the observations.

The calculation of the ShapiroWilk test of normality gave a $P<5 \%$, indicating that the data did not have a normal distribution. The Krukal-Wallis test was then used for the observation times after treatment and on the number of sprays per treatment.

\section{RESULTS}

\section{Essential oils and hydrosol yield.}

The first observation in Table 1 shows extremely low yields of essential oils obtained from the four plants. The lowest was from colocynth at $0.2 \%$. The highest is that of hyssop which is around $0.5 \%$. On the other hand, the quantities of hydrosols obtained were relatively large, ranging from 600 to $720 \mathrm{ml}$.

Table 1. Plants evaluated for their acaricidal activity against Oligonychus afrasiaticus, their essential oil yield and their hydrosol amount

\begin{tabular}{l|lccc}
\hline \multicolumn{1}{c|}{ Scientific name } & \multicolumn{1}{c}{ Family } & $\begin{array}{c}\text { Used plant } \\
\text { parts }\end{array}$ & $\begin{array}{c}\text { Oil yield } \\
(\%)\end{array}$ & $\begin{array}{c}\text { Collected } \\
\text { hydrosol (ml) }\end{array}$ \\
\hline Ocimum basilicum & Lamiaceae & & 0.40 & 650 \\
Hyssopus officinalis & Lamiaceae & All & 0.50 & 720 \\
Peganum harmala & Zygophyllaceae & & 0.46 & 600 \\
Citrullus colocynthis & Cucurbitaceae & & 0.20 & 640 \\
\hline
\end{tabular}


Extract toxicity (hydrosol) effect.

Figs. 5, 6 and 7, show that the highest mite mortality rate is recorded for hyssop hydrosol, which varies between $17 \%$ for $2 \mathrm{~h}$ after 2 sprays and up to $91 \%$ for $8 \mathrm{~h}$ after 4 sprays. The next most efficacious hydrosol was from colocynth, characterized by a relatively strong acaricidal effect, with a mortality rate varying between $12 \%$ and $64 \%$, whereas the lowest rate is observed with harmel hydrosol, which ranges from $0 \%$ for $2 \mathrm{~h}$ after 2 sprays to $2 \%$ for $8 \mathrm{~h}$ after application of 4 sprays. Basil hydrosol generally had a delayed acaricidal effect, initially displaying a weak effect and then producing variable mortality, ranging between $0 \%$ and $62 \%$.

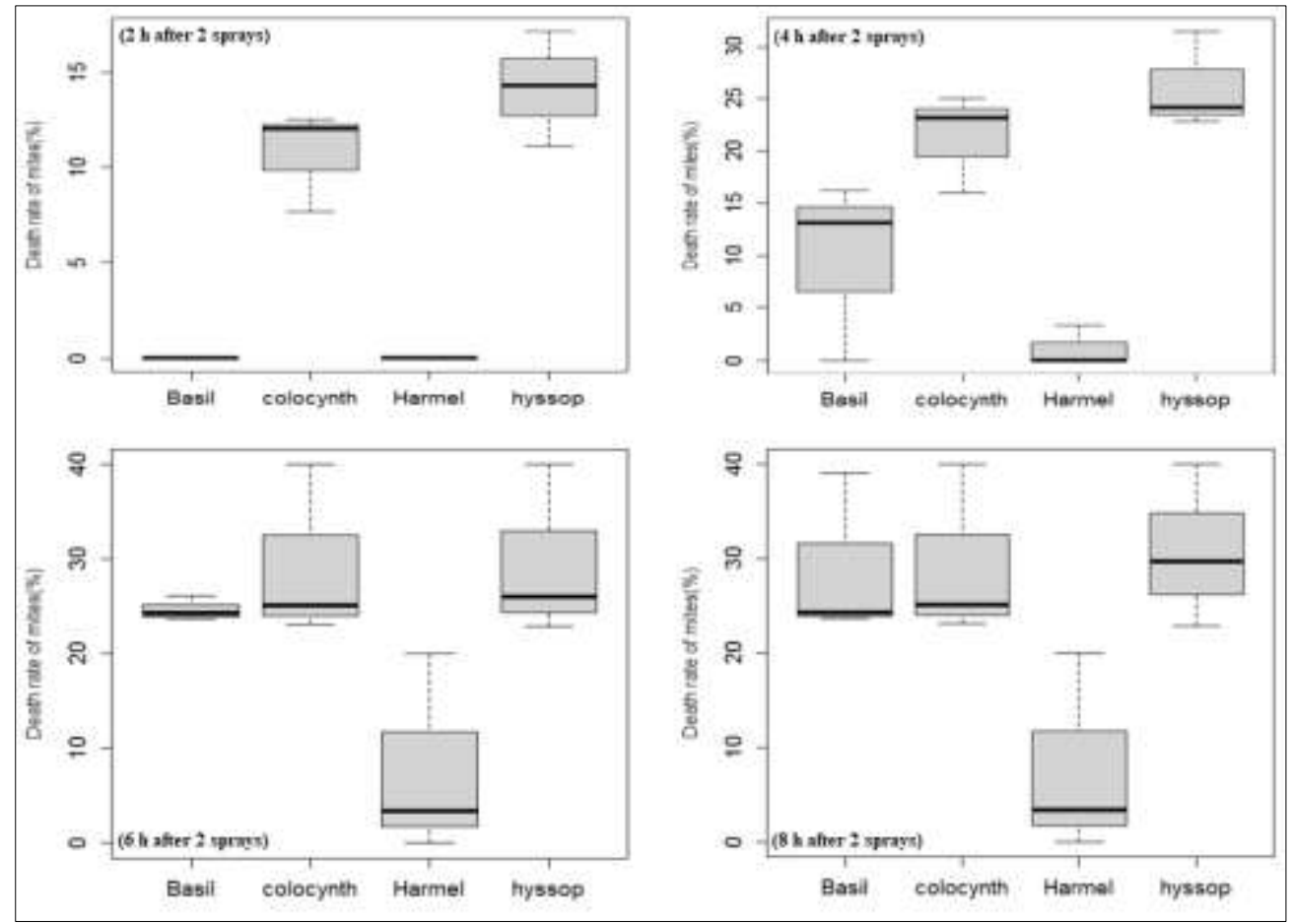

Fig. 5. Mite mortality rate according to the hydrosols of the 4 plants over 4 observation times, after 2 sprays. The bold horizontal segments are the medians. The dotted vertical segments are the standard deviations.

After 2 sprays, Fig. 5 illustrates the late acaricidal effect of the hydrosols of the two plants, basil and harmel. These extracts increase slowly the mortality rates of the mites over time, while extracts of colocynth and hyssop produce higher mortality relatively early, already 2 hours after treatment. 


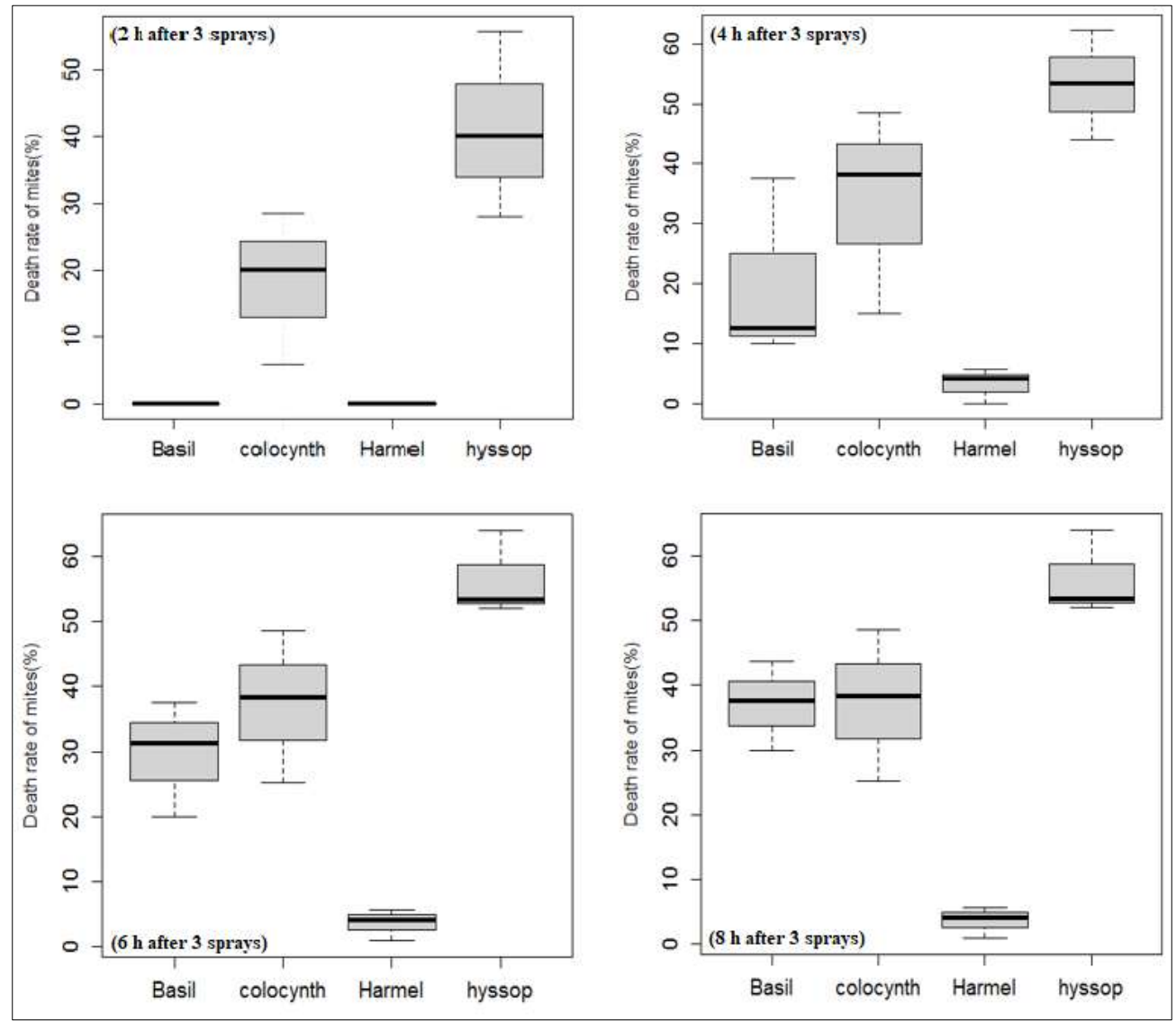

Fig. 6. Mite mortality rate according to the hydrosols of the 4 plants over 4 observation times, after 3 sprays. The bold horizontal segments are the medians. The dotted vertical segments are the standard deviations.

After 3 sprays, the result shown in Fig. 6 is a low or even neutral acaricidal effect of harmel hydrosol in comparison with that of hyssop, during all 4 phases of observation. On the other hand, the mite mortality rates for hydrosols of the other two plants basil and colocynth remain relatively stable, particularly for the last 2 observations. 


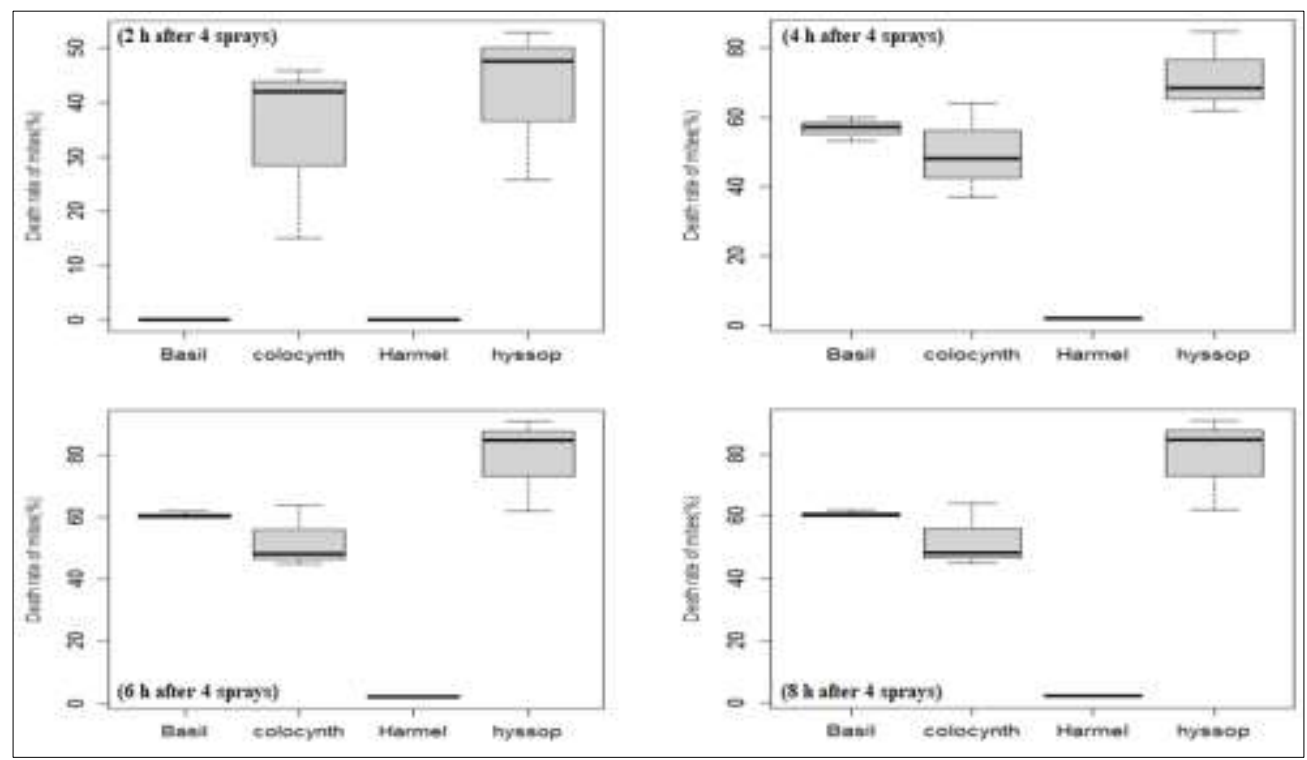

Fig. 7. Mite mortality rate according to the hydrosols of the 4 plants over 4 observation times, after 4 sprays. The bold horizontal segments are the medians. The dotted vertical segments are the standard deviations.

After 4 sprays, indication of Fig. 7 is the lack of acaricidal effect from harmel at all 4 observation phases. The hydrosol of hyssop has a strong acaricidal effect and exhibits the highest mortality rate after 4 sprays and at all 4 observation phases. The hydrosol of basil and colocynth expresses a relatively important acaricidal effect for 4 sprays and during the 4 observation phases, except for basil at the first time $(2 \mathrm{~h})$ of treatment, where the effect is poor.

\section{Mite mortality rates based on the plant hydrosols.}

Kruskal-Wallis test calculations gave the following results: $\chi^{2}=69.567$, df $=3, P$-value $=5.285 \mathrm{e}^{-15}$.

The $P$-value reflects the existence of a highly significant difference between the medians of the 4 groups (Fig. 8).

In order to determine the difference between the 4 groups, multiple comparison tests were performed using the Bonferroni adjustment method (Table 3).

Table 3. Level of difference in mite mortality rates due to the hydrosols of 4 plants

\begin{tabular}{c|ccc}
\hline & Basil & Colocynth & Hyssop \\
\hline Colocynth & 0.79210 & - & - \\
Hyssop & 0.00362 & 0.03644 & - \\
Harmel & 0.00038 & $5.1 \mathrm{e}-12$ & $2.4 \mathrm{e}-12$ \\
\hline
\end{tabular}


The lowest acaricidal effect reported is that of harmel hydrosol with a maximum mortality rate of $6 \%$. The highest is that of hyssop with the maximum mortality rate reaching $91 \%$.
The intermediate acaricidal effect is obtained by the hydrosols of the two plants, basil and colocynth, with corresponding consecutive maximum mortality rates of $62 \%$ and $64 \%$ (Fig. 8).

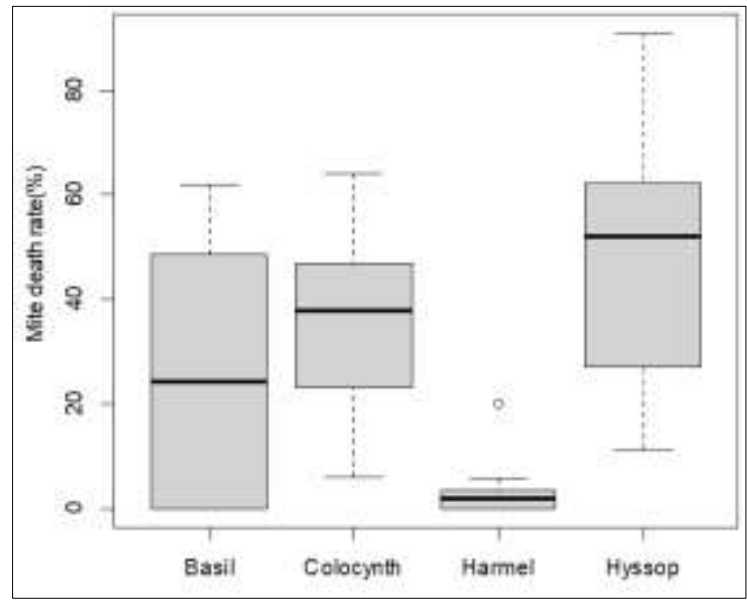

Fig. 8. Effect of hydrosols from 4 plants on the mite mortality rate. The bold horizontal segments are the medians. The dotted vertical segments are the standard deviations.

\section{Mite mortality rates based on the observation times.}

The calculation of the KruskalWallis test gave the following results: $\chi^{2}=$ $24.091, \mathrm{df}=3, P$-value $=2.391 \mathrm{e}^{-05}$.
The $P$-value reflects the existence of a highly significant difference between the medians of the 4 groups studied (Table 4).

Table 4. Level of difference in mite mortality rates between 4 observation times after treatment

\begin{tabular}{l|ccc}
\hline & 2 hours & 4 hours & 6 hours \\
\hline 4 hours & 0.00677 & - & - \\
6 hours & 0.00020 & 1.00000 & - \\
8 hours & 0.00012 & 1.00000 & 1.00000 \\
\hline
\end{tabular}


Mite mortality rates of mites based on the number of sprays

The calculation of the KruskalWallis test gave the following results: $\chi^{2}=$ $17.114, \mathrm{df}=2, P$-value $=0.0001922$.
The $P$-value reflects the existence of a highly significant difference between the 4 groups studied (Table 5).

Table 5. Level of difference in mite mortality rates between the numbers of applied sprays

\begin{tabular}{l|cc}
\hline & 2 sprays & 3 sprays \\
\hline 3 sprays & 0.04905 & - \\
4 sprays & 0.00038 & 0.06236 \\
\hline
\end{tabular}

\section{DISCUSSION}

There are different methods for extracting bioactive compounds from aromatic, tinctorial and lignocellulosic rich plants such as cold expression, volatile organic solvent, liquefied gas, fluid in the supercritical state, microwave, ultrasonic, water vapor, and hydrodistillation (Peyron and Richard 1992; Qin 1993; Sankarikutty and Narayanan 1993; Starmans and Nijhuis 1996; Martini and Seiller 1999; Wang and Weller 2006). Among all these processes, hydrodistillation is the most widely used in industrial production of essential oils (Mastelic 2001). The main reasons for this preference are related to the ease of implementation of the process, its selectivity and therefore the quality of the products obtained. Furthermore, hydrodistillation facilities are relatively simple to design and construct (Ganou 1993).

In our work, the resulting essential oil (EO) yields were extremely low (not exceeding $0.4 \%$ for basil). Akono et al. (2012) reported a yield of $0.11 \%$ EO for $O$. basilicum using the hydrodistillation technique. Additionally, Rey et al. (2004) reported a yield of $0.57 \%$ EO for H. officinalis in the fruiting phase, which is not far from the result of the Tunisian Journal of Plant Protection present study (for the same phenological stage of the plant). According to Idrissi Hassani (1999), the EO yield of Peganum harmala seeds reached $10 \%$.

The first observation is the fairly significant bioacaricidal effect of hyssop, compared to the other 3 plants studied. It should also be noted that the greater the quantity of hydrosol applied to the pest and the longer the product is left to act, the higher is the mortality rate, with the exception of harmel hydrosol.

The $P$-values resulting from the Kruscal-Wallis test revealed the existence of differences in the acaricidal effect between the plants studied, particularly between hyssop and harmel. Indeed, hyssop differs from other plants by the release of strong odors which, according to Attou (2017) originate from a set of products such as ketones and diketones (diones) and the neurotoxicity is explained by the strong affinity of ketones to lipids; this results in passage through the bloodbrain barrier, destruction of the myelin sheaths and electrical disturbances of neurons with excitation then depression, which are probably the cause of the death of mites. The difference is clearly apparent in the death rates between the 4 observation times. This can explain how the product acts on the pest, which is 
probably by contact acting on the mite's synapses and neurotransmitters. Piochon (2008) stated that several hydrosols exerted interesting biological activities and sometimes stronger than that of the corresponding essential oil. The use of biopesticides against this pest mite, in view of their importance, has been the subject of several recent studies, such as that of Archita et al. (2015) and Júnior de Andrade et al. (2020). This study supports the suggestion that plant extracts are potentially useful biopesticides for combating agricultural pests while preserving the environment. It would therefore be interesting to study and explore the biopesticide effects of other spontaneous or cultivated plants and to extend their use in order to minimize the use of chemical pesticides harmful to man and his environment.

\section{RESUME}

Babaz Y., Guezoul O. et Bouras N. 2021. Evaluation en conditions de laboratoire de l'efficacité de quatre extraits de plantes spontanées de la Vallée du Mzab (Algérie) contre l'acarien du palmier dattier (Oligonychus afrasiaticus). Tunisian Journal of Plant Protection 16 (2): 29-41.

Des essais ont été menés, pour tester les hydrolats de 4 plantes spontanées, sur l'acarien du palmier dattier, Oligonychus afrasiaticus, un ravageur du palmier dattier important en Algérie. Les extraits de ces plantes (basilic, Harmel, coloquinte et hysope) testés contre l'acarien du palmier dattier ont donné des résultats prometteurs. Les quantités d'huiles essentielles extraites des 4 plantes étaient extrêmement faibles, c'est pourquoi seuls des hydrolats ont été utilisés. Les résultats obtenus varient en fonction du nombre de pulvérisations et du temps de lecture après le traitement. L'extrait d'hysope a provoqué un taux de mortalité élevé de $91 \%$, suivi des extraits de coloquinte et de basilic avec des taux de mortalité moyens de $64 \%$ et $62 \%$, respectivement. Le taux de mortalité le plus faible, soit $6 \%$, s'est exprimé lors de l'application de l'extrait de harmel.

Mots clés : Acarien, extraits de plantes, Oligonychus afrasiaticus, palmier dattier, plantes spontanées, Sahara septentrional

ملقيم كفاعة أربعة مستخلصات نباتات برية في ظروف المخبر ضد حلم نخيل التمر (بوفروه/الغبيره/حلم الغبار، (Oligonychus afrasiaticus Tunisian Journal of Plant Protection 16 (2): 29-41.

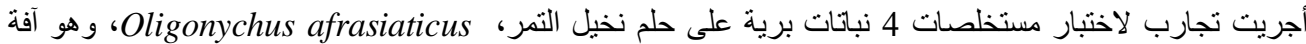

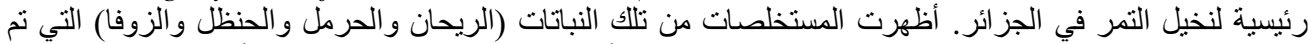

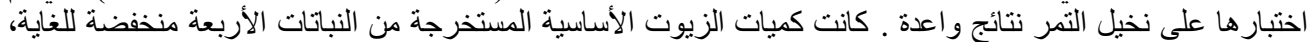

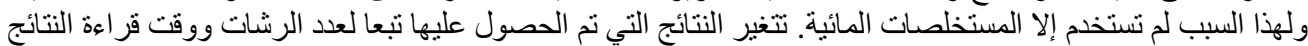

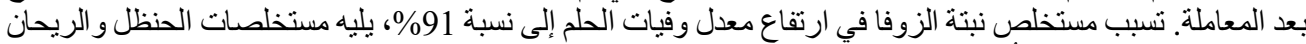

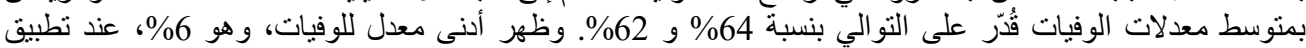

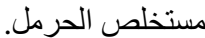

كلمات مفتاحية: حلم، الصحر اء الثمالية، مستخلصات نباتية، نخيل التمر، نباتات برية، Oligonychus afrasiaticus 


\section{LITERATURE CITED}

Abbassi, K., Mergaoui, L., Atay-Kadiri, Z., Stambouli, A., and Ghaout, S. 2003. Effets des extraits de Peganum harmala (Zygophyllacae) sur le criquet pèlerin (Schistocerca gregaria Forskål, 1775). Zoologica baetica, 13/14: 203-217.

Afnor, 1986. Recueil des Normes Française, huiles essentielles, AFNOR. Paris, France, 57 pp.

Akono, N.P., Belong, P., Tchoumbougnang, F., Bakwo Fils, E.M., and Fankem, H. 2012. Effets insecticides des huiles essentielles des feuilles Ocimum spp. sur les adultes d'Anopheles funestus. Journal of Applied Biosciences 59: 4340-4348.

Archita, B. Somnath, R., Gautam, H., Foridur Rahman, B., Azizur, R., Dwiban, P., and Narayanannair M. 2015. Clove Oil Efficacy on the Red Spider Mite, Oligonychus coffeae Nietner (Acari: Tetranychidae) Infesting Tea Plants. Zoological Society, Kolkata, India 1: 92-96.

Attou, A. 2017. Détermination de la composition chimique des huiles essentielles de quatre plantes aromatiques de l'ouest algérien (Région d'Ain Témouchent) étude de leurs activités antioxydante et antimicrobienne. Thèse de Doctorat, Université de Tlemcene, Algérie, 82 pp.

Basta, A., and Spooner-Hart, R.N. 2002. Efficacy of an extract of dorrigo pepper against twospotted mite and greenhouse thrips. Pages 471-476. In: Spray oils beyond 2000. Beattie, G.A.C., Waston, D.M., Stevens, M.L., Rae, D.J., and Spooner-Hart, R.N, Eds. University of Western Sydney, Sydney, Australia.

Bruneton, J. 2016. Pharmacognosie - Phytochimie, plantes médicinales - ( $5^{\circ}$ Edition). Lavoisier. France, $1488 \mathrm{p}$

Chiasson, H., Belanger, A., Bostanian, N., Vincent, C., and Poliquin, A. 2001. Acaricidal properties of Artemisia absinthum and Tanacetum vulgare (Asteracae) essential oils obtained by three methods of extraction. Journal of Economic Entomology 94: 167171.

De Montaigne, M., and Fall, A.M. 1986. La protection phytosanitaire des palmeraies en Mauritanie. Phytoma 9: 41-45.

Doumandji-Mitiche, B., and Doumandji, S. 1993. La lutte biologique contre les déprédateurs des cultures, Ed. O.P.U., Alger, Algérie, 94 pp.

Ganou, L. 1993. Contribution à l'étude de mécanismes fondamentaux de l'hydrodistillation des huiles essentielles, Thèse de doctorat $\mathrm{n}^{\circ} 689$, Institut National Polytechnique de Toulouse, France, 241 pp.
Guessoum, M. 1986. Approach of a bio-ecological study of the mite Oligonychus afrasiaticus (Boufaroua) on date palms. Annales de l'Institut Agronomique El Harrach, Algérie 10: $153-166$

Hay, R.K.M., and Waterman, P.G. 1993. Volatile oil crops. Wiley, Essex, United Kingdom, 185 pp.

Hussain, A.A. 1974. Dates palms and dates with their pests in Iraq. University of Baghdad, Iraq, $166 \mathrm{pp}$.

Idrissi Hassani, L.M., and El Hadek M. 1999. Analyse de la composition de l'huile de Peganum harmala L. (Zygophyllaceae). Acta Botanica Gallica 146: 353-359.

Idrissi Hassani, L.M., and Hermas, J. 2008. Effets de l'alimentation en Peganum harmala L. (Zygophyllaceae) sur le tube digestif du criquet pèlerin Schistocerca gregaria Forsk. (Orthoptera, Acrididae). Zoologica Baetica 19: 71-84.

Isman, M.B. 2000. Plant essential oils for pest and disease management. Crop protection 19: 603-608.

Isman, M.B. 2001. Pesticides based on plant essential oils for management of plant pests and diseases. Pages 1-9. In: Proceedings of International symposium on development of natural pesticides from forest resources. October 8-10, 2001, Forest Research Institute, Seoul, Republic of Korea.

Jovana, D., François, K., and Philippe, J. 2014. Les bio-pesticides, compléments et alternatives aux produits phytosanitaires chimiques. Biotechnology, Agronomy, Society and Environment 18: 220-232.

Júnior de Andrade, D., Martins da Rocha, C., Soares de Matos, S.T., and Zanardi, O.Z. 2020. Oxymatrine-based bioacaricide as a management tool against Oligonychus ilicis (McGregor) (Acari: Tetranychidae) in coffee, Crop Protection 134: 105182.

Kruskall, W.H., and Wallis, W.A. 1953. Use of ranks in one-criterion variance analysis. The Journal of the American Statistical Association 48: 907-911.

Martini, M.C., and Seiller, M. 1999. Actifs et additifs en cosmétologie. Procédés d'extraction des huiles essentielles. Editions Tec and Doc, Editions Médicales Internationales, France $563 \mathrm{pp}$.

Mastelic, J. 2001. The essential oil co-distillation by superheated vapour of organic solvents from aromatic plants. Flavour and Fragrance Journal 16: 370-373.

Peyron, L., and Richard H. 1992. L'extraction des épices et herbes aromatiques et les différents types d'extraits. Epices et aromates. Tec et 
Doc - Lavoisier, APRIA., Paris, France, 339 pp.

Piochon, M. 2008. Etude des huiles essentielles d'espèces végétales de la flore laurentienne: composition chimique, activités pharmacologiques et hémi-synthèse. Mémoire présenté à l'Université de Québec, Canada, 156 pp.

Qin, C.J. 1993. Properties and Analysis. Pages 54915501. In: Encyclopedia of Food Science, Food Technology and Nutrition. Academic Press, USA.

Rey, Ch., Carron, C. A., Cottagnoud, A., Bruttin B., and Carlen, Ch. 2004. La variété d'hysope officinale «Perlay». Revue Suisse de Viticulture, Arboriculture, Horticulture 36: 337-341.

Sankarikutty, B., and Narayanan, C.S. 1993. Isolation and Production. Pages 2185-2189. In:
Encyclopedia of Food Science, Food Technology and Nutrition. Academic Press, USA.

Singh, G., and Upadhyyay, R.K. 1993. Essential oils: a potent source of natural pesticides. Journal of Scientific and Industrial Research 52: 676683.

Starmans, D.A.J., and Nijhuis, 1996. Extraction of secondary metabolites from plant material: A review. Trends in Food Science and Technology 7:191-197.

Thakore, Y. 2006. The biopesticide market for global agriculture use. Industrial Biotechnology 2: 194-208.

Wang, L., and Weller, C. 2006. Recent advances in extraction of nutraceuticals from plants. Trends in Food Science and Technology 17: 300-312. 
